\title{
ENDOSCOPIC TREATMENT FOR GASTRIC PERFORATION USING T-tag AND A PLASTIC PROTECTION CHAMBER: a short-term survival study
}

\author{
Kiyoshi HASHIBA, Pablo R. SIQUEIRA, Horus A. BRASIL, Marco Aurélio D’ASSUNÇÃO, \\ Daniel MORIBE and Jorge Carim CASSAB
}

\begin{abstract}
Context - The endoscopic gastric perforation is a consequence of some endoscopic procedures and now a way to manage abdominal organs. This is the reason why endoscopists are studying a safe endoscopic repair. Objective - To evaluate an endoscopic closure method for the gastric opening in natural orifice transenteric surgery Design - Short-term survival animal study. Methods Ten White Landrace pigs underwent a gastric perforation of $1.8 \mathrm{~cm}$ in diameter under general anesthesia. The opening was repaired with stitch assembled in a T-tag anchor placed through the gastric wall with a needle. A plastic transparent chamber, adapted to the endoscope tip protected the abdominal organs from the needle puncture outside the stomach. Six T-tags were placed in most cases and the stitches were tied with a metallic tie-knot, forming three sutures. The animals received liquids in the same operative day. One shoot antibiotic was used. The leakage test was performed with a forceps and by air distention. Results - No complication was detected in the postoperative course. One month later the endoscopy revealed a scar and some suture material was observed in all animals. The antral anterior gastric wall was clear with few adhesions in the laparotomy performed in the same time. The adhesions were intense in an animal in which a cholecystectomy was performed before the repair. Conclusion - The endoscopic repair using T-tag and a protector chamber is feasible, easy to perform and safe. Further studies are needed to show the real value of this kind of procedure. HEADINGS - Endoscopy gastrointestinal. Intestinal perforation. Swine.
\end{abstract}

\section{INTRODUCTION}

Perforation in the gastrointestinal tract during endoscopy is not a rare event. Nowadays the perforation can be a step of the endoscopic procedure, like in some mucosectomy and in natural orifice transenteric surgery (NOTES) procedure. Many techniques were proposed for the repair, but some of them are very complex ${ }^{(9)}$. The use of T-tag seems to be the simplest method and this is, probably, the reason why many studies are made with this device ${ }^{(6,8)}$. However, the needle insertion in the peritoneal cavity, through the gastrointestinal wall, as proposed in some of them, seems to be dangerous ${ }^{(3,11,12)}$. In this presented study a chamber adapted to the endoscope tip was used to protect other abdominal organs during the T-tag anchor placement in order to make an interrupted suture which was applied to close a full-thickness gastric perforation.

\section{METHODS}

This study included 10 farm pigs weighing approximately 30 to $35 \mathrm{~kg}$. No oral food intake was allowed 24 hours before experiments. The animals were got under general anesthesia, ventilated with $100 \%$ oxygen and monitored with pulse oximeter. All procedures were performed with the animal in the supine position. The gastric mucosa did not receive previous treatment.

The area for NOTES access was chose and guided by transillumination and abdominal digital pressure, a 14-gauge needle was passed through the anterior abdominal wall into the stomach, followed by passage of a guidewire (METII-35-480, Cook Endoscopy, Winston-Salem, NC, USA) through the needle. This wire was captured into the working channel of a conventional gastrointestinal endoscope by means of a biopsy forceps (FB-21K-1, Olympus Latin America, Miami, FL, USA) and then

\footnotetext{
The following authors report that they have no disclosure relevant to this publication: Pablo R.de Siqueira. Marco Aurélio D’Assunção, Horus A. Brasil, Daniel Moribe. Kiyoshi Hashiba acts as a consultant for Cook Endoscopy

Hospital Sírio Libanês Experimental Center and Endoscopic Unit, São Paulo SP, Brazi

Correspondence: Dr. Kiyoshi Hashiba - Rua Dona Adma Jafet, 90 - CEP: 01308-050 - Sao Paulo - SP, Brazil. Email: hashiba@attglobal.net
} 
the scope and the guide wire were pulled to the mouth. With the stomach partially deflated, a $1.8 \mathrm{~cm}$ in diameter, TTS balloon (QD-18x8, Cook Endoscopy) was passed by the working channel over the wire, advanced across the gastric wall and totally inflated in order to dilate the needle puncture. A laparoscopy using a 0o view optical device (26003AEA, Storz, Tuttlingen, Germany) placed into an $11 \mathrm{~mm}$ umbilical trocar (30103 MP, Storz, Tuttlingen, Germany), was performed to exclude iatrogenic injury during the peritoneal access.

A specially developed plastic chamber (prototype, Cook Endoscopy) is attached to the tip of the conventional gastrointestinal endoscope (GIF-160, Olympus). The chamber has a lateral window that allows the placement of the gastric wall inside (Figures 1 and 2).

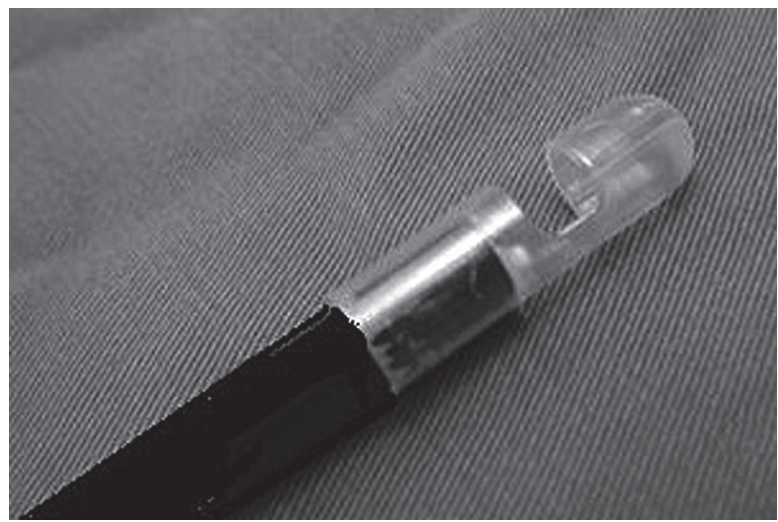

FIGURE 1. The plastic chamber

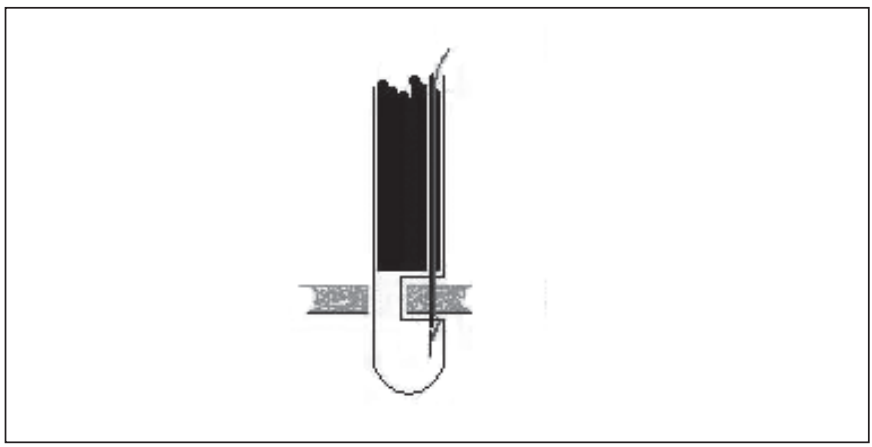

FIGURE 2. Schematic view of the suture

Chamber characteristics: length: $4.2 \mathrm{~cm}$, window: $8 \mathrm{~mm}$ in length and 2/3 of the circumference, length distal to the window: $1.5 \mathrm{~cm}$, length from the endoscope tip to the window: $8 \mathrm{~mm}$.

The suturing procedure was performed with a T-shaped anchor suture T-tag (prototype, Cook Endoscopy). The suture was loaded into a needle assembled in a narrow plastic tube. The needle is placed at the end of a metal tube and its sharp end remains protected inside the tube, but can be exposed by pushing the metal tube. This set was inserted through the working channel, perforating the wall supported by the chamber as showed on
Figure 3. After the puncture, the T-tag remains near the gastric serosa in a place at the side of the gastric opening. The endoscope was retrieved, loaded with another T-tag, rotated at the opposite side of the previous puncture and the procedure repeated. So, at the end of these two punctures, two stitches are placed in the side of the gastric perforation (Figure 4). Both stitches are put together with a tie-knot (prototype, Cook Endoscopy) under endoscopic visual control.

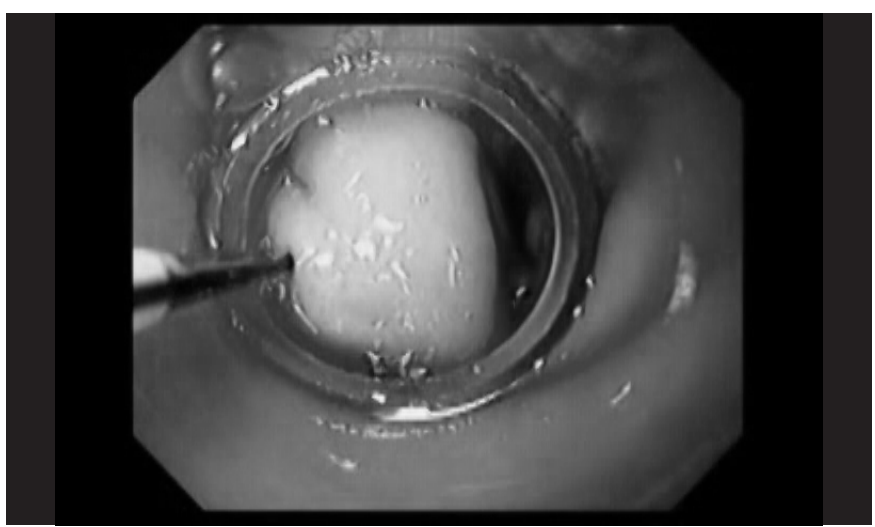

FIGURE 3. Endoscopic view of the suture

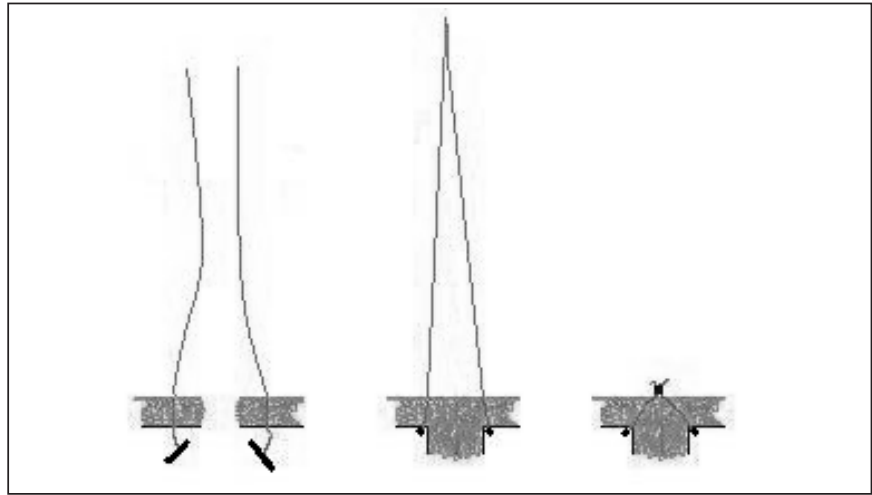

FIGURE 4. The T-tag suture

The stitches were cut with scissors (FS-3L-1, Olympus), one at a time. At the end of all procedures, a remaining opening was searched using a permanent biopsy forceps (FB-19K-1, Olympus). With the peritoneal cavity totally filled with saline solution, a leakage test was performed with air injected by the endoscope to maximum capacity. The point of failure was defined as the point at which the first sign of air was seen bubbling from the repaired wound. When an air leakage was detected, an endoscopic metallic clip (HX-600-090, Olympus) was placed and the test was repeated. All animals received liquids in the first 12 hours and regular food after that period. One shot of antibiotics (Cefazoline $2 \mathrm{~g}$ ) was given 2 days postoperatively. One month later, an endoscopic inspection and a laparotomy were performed under the same schedule using general anesthesia. The animals were sacrificed after this second experimental session using embutramide and trimethyllammonium iodide. 
A small piece of gastric tissue with the repair in place was sent for histology.

This study was approved by the Hospital Sírio Libanês Institutional Animal Care and Use Committee.

\section{RESULTS}

The complete opening ( $1.8 \mathrm{~cm}$ in diameter) was achieved in a total time that ranged from 15 to 20 minutes.

The transparency of the wall chamber was enough to identify all places. Therefore its insertion in the peritoneal cavity occurred without trauma. In nine animals the complete closure was achieved with three pairs of sutures (Figure 5) and in one pig with three sutures, two clips were placed to close a remaining opening detected by forceps inspection. In one pig only four T-tags were placed and the stitches were put together in a crossing design.

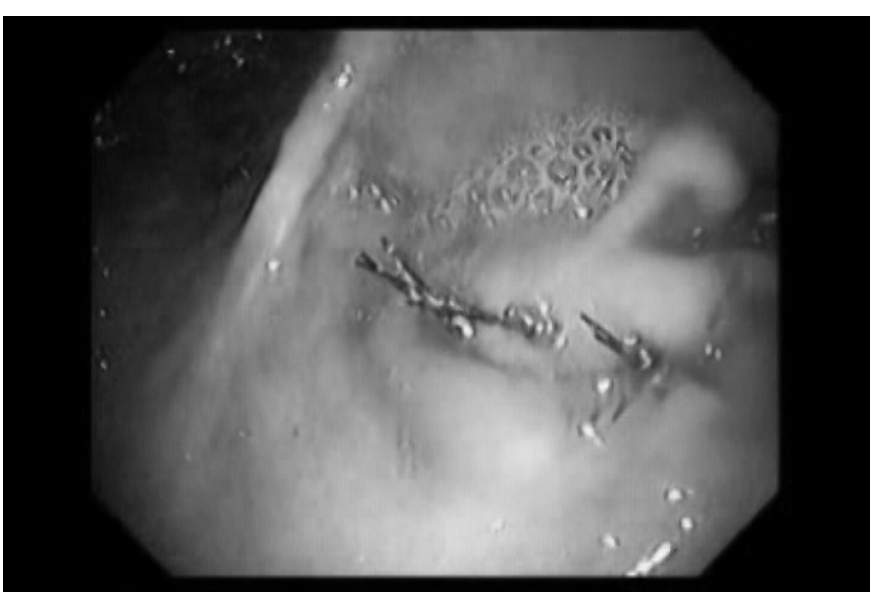

FIGURE 5. The suturing procedure is completed with 3 sutures. The tie knot is clearly seen.

The total time to place one suture with T-tag anchor ranged from 5 to 8 minutes. The animals were monitored clinically until euthanasia and no postoperative complications were detected.

The endoscopy revealed a scar in all animals (Figure 6A). Isolated stitches without tie-knots were found in three animals. T-tag anchors were observed in six animals. In eight animals, the laparotomy showed local adhesions of the omentum and the place of the gastric opening was identified (Figure 6B). In the remaining two animals the anterior face of the antrum was not seen due to adherences involving the liver and omentum and they had to be cut. The T-tag, stitches and tie-knot were also not found in the peritoneal cavity. The histology showed an inflammatory process in the submucosa, extending to the muscular layer and serosa, consisting of neutrophils, lymphocytes and histiocytes, together with fibrous and vascular proliferation. In some cases the two portions of sectioned muscular layer were in close proximity, intermixed with inflammatory cells and mild fibrosis. In all animals there was a complete restoration of the mucosal lining (Figure 7).

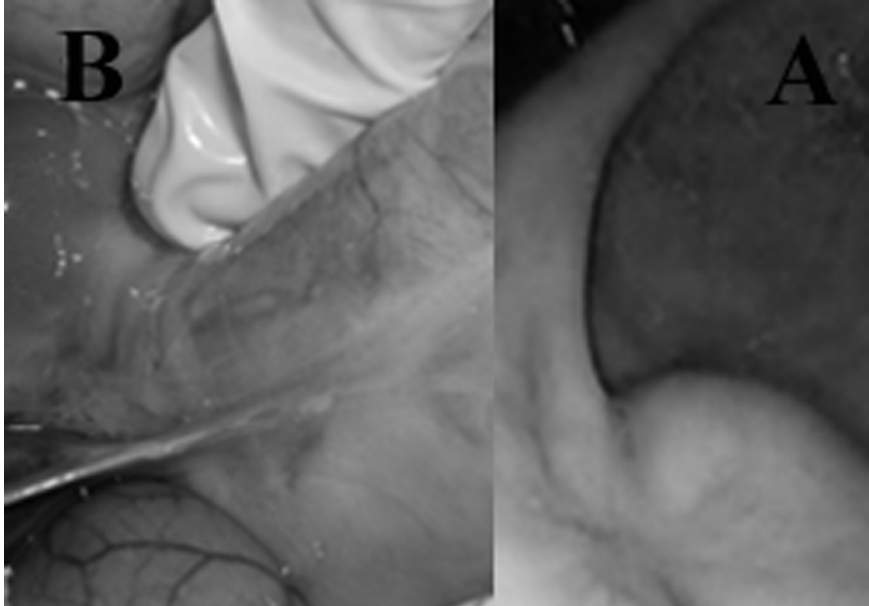

FIGURE 6. The repair place scar: Endoscopic (A) and laparoscopic (B) view

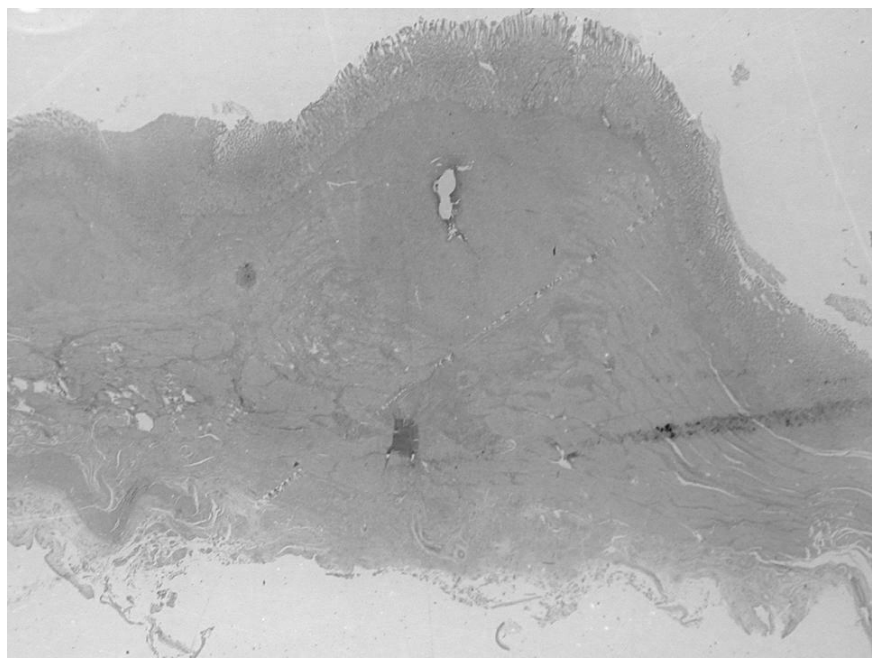

FIGURE 7. The histology shows complete restoration of the mucosal lining.

\section{DISCUSSION}

The occurrence of perforation in endoscopic therapeutic procedures increased the need of an endoscopic method for the repair. Beside the use of clips, many endoscopic methods with this aim are in development ${ }^{(1,2,4,5,6,10)}$.

Most devices proposed use stitches to make a suture in the gastrointestinal tract wall. The use of T-tags is not new ${ }^{(14)}$. As a matter of fact, the first device used for this aim was not for perforation repair, but to treat gastroesophageal reflux disease $^{(13)}$. In this procedure the stitch must be retrieved to the mouth twice. The use of a T-tag avoids this step of the procedure. However, the insertion of the T-tag through the wall through a needle is a blind procedure. This means that the operator cannot see what the tip of the needle finds when it passes the wall, even with the help of a limitation mechanism to avoid inserting a needle too deeply ${ }^{(3)}$. Sometimes, mainly when the intestine is distended, in the final step of a long procedure, the puncture can reach another organ. 
Experimental studies in gastrointestinal perforation repair showed that this event is not so rare when the perforation is performed with T-tag $(1,2,4,5,6,7,10,12,13)$. The idea of using a chamber to protect other abdominal organs seems to be very important when the closure is performed with $\mathrm{T}-\operatorname{tag}^{(3,11,12)}$.

One objection raised in relation to the technique presented in this study is the attachment of the gastric wall, in the context of the mucosal surface not by the serosa as is mandatory in surgical rules. As no complication occurred in the animals postoperative course, it would be interesting to know what happens with the T-tag during the repair process. This is the reason why the control approach with endoscopy and laparotomy were performed one month later. It was noticed that, despite the controversial technique applied, the repair was as expected, with few adhesions in most animals. The endoscopic view revealed a scar. Sometimes the material used in the suture was found in the scar site. This suggests that stitches and T-tags migrate to the lumen and are eliminated with residual foods. On the other hand, the histology confirmed the good result observed through endoscopy and laparotomy, including repair of the gastric wall layers.
In conclusion, the protection chamber represents an improvement in the T-tag suture for an opening in the gastric wall. When an opening represents an acceptable event, a full-thickness resection of the gastric wall could be an option for endoscopic mucosal resection or SMD, techniques that are time-consuming, expensive and very often followed by pneumoperitoneum. It would be a possibility when gastric wall limited resection was indicated, such as in selected cases of GIST, avoiding a laparotomy or a laparoscopic procedure.

\section{ACKNOWLEDGMENTS}

We thank Ms. Alvamar Helena de Campos Andrade Lamparelli for the manuscript revision and Mr Vihar Surti, Senior Research Engineer, Cook Endoscopy, Winston-Salem, $\mathrm{NC}$, for the development of the set for the suturing procedure.

The endoscope system and other devices were kindly provided for the study by Olympus Latinamerica, Miami, FL, USA, and Cook Endoscopy, Winston Salem, NC, USA

Hashiba K, Siqueira PR, Brasil HA, D’Assunção MA, Moribe D, Cassab JC. Tratamento endoscópico para perfuração gástrica por sutura utilizando dispositivos em T associados à câmara plástica protetora: estudo com curto tempo de sobrevida. Arq Gastroenterol. 2011 ; 48(2): 159-62.

RESUMO - Contexto - A perfuração gástrica pode ser consequência de alguns procedimentos endoscópicos, atualmente, produzida intencionalmente para acesso a alguns órgãos com o advento da cirurgia transluminal endoscópica por orifícios naturais. Esta é a razão para que os endoscopistas estudem uma maneira segura de reparar estas lesões por via endoscópica. Objetivo - Avaliar um novo método de fechamento das perfurações gástricas utilizadas para acesso ao NOTES. Modelo de estudo - Pesquisa em modelos animais com curto tempo de sobrevida. Método - Dez porcos da raça White Landrace, foram submetidos a perfuração gástrica de 1,8 cm, monitorizados e sob anestesia geral. A abertura gástrica foi reparada com dispositivo especial constituído por agulha em forma de T montada com fio (T-tag), inserida, por via endoscópica, nas bordas do ferimento perfurando a parede gástrica e fixando-se a ela como uma âncora. Uma câmara plástica protetora, especialmente desenvolvida, foi adaptada à ponta do endoscópio para proteção dos órgãos subjacentes. Seis T-tags foram inseridos na maioria dos casos e os pontos foram amarrados e fixados com auxílio de outro dispositivo metálico de contenção do nó denominado "tie-knot", formando três suturas. Um teste de vazamento do tipo manobra do borracheiro era realizado ao término do procedimento. Os animais recebiam líquido no pós-operatório imediato. Foi usada profilaxia antibiótica. Resultados - Não houve complicações. Um mês depois, a endoscopia de controle revelou cicatriz e alguns restos de sutura. A laparotomia, feita no mesmo tempo, revelou poucas aderências na face anterior do antro. Conclusão - O reparo endoscópico com T-tags e câmara protetora parece ser efetiva, fácil e segura. Estudos maiores e com maior tempo são necessários para confirmar estes resultados e a utilidade deste procedimento

DESCRITORES - Endoscopia gastrointestinal. Perfuração intestinal. Suínos.

\section{REFERENCES}

1. Bergström M, Ikeda K, Swain P, Park PO. Transgastric anastomosis by using flexible endoscopy in a porcine model (with video). Gastrointest Endosc. 2006;65:307-12.

2. Fritscher-Ravens A, Mosse CA, Mills TN, Mukherjee D, Park PO, Swain P. A through-the-scope device for suturing and tissue approximation under EUS control. Gastrointest Endosc. 2002;56:737-42.

3. Ikeda K, Fritscher-Ravens A, Mosse A, Mills T, Tajiri H, Swain CP. Endoscopic full-thickness resection with sutured closure in a porcine model. Gastrointest Endosc. 2005;62:122-9

4. Ikeda K, Tajiri H. Evaluation of bifurcated double T-bar suturing device for effective closure of gastric perforation in ex vivo porcine models - aimed at clinical application of NOTES [abstract]. Gastrointest Endosc. 2008;67:AB116.

5. Pham BV, Raju GS, Ahmed I, Brinning D, Chung S, Cotton P, Gostout CJ, Hawes RH, Kalloo AN, Kantsevov SV, Pasricha PJ. Immediate endoscopic closure of colon perforation by using a prototype endoscopic suturing device: feasibility and outcome in a porcine model (with video). Gastrointest Endosc. 2006;64:113-9.

6. Rahmani EY, Freeman L, Sherman S, Chiorean MV, Selzer DJ. New method of gastric incision closure in NOTES: short term survival study. Gastrointest Endosc. 2008;67:AB121.

7. Raju GS, Fritscher-Ravens A, Rothstein R, Swain P, Gelrud A, Ahmed I, Gomez G, Winny M, Sonnanstine T, Bergström M, Park PO. Endoscopic closure of colon perforation compared to surgery in a porcine model: a randomized controlled trial (with video). Gastrointest Endosc. 2008;68:324-32.

8. Rothstein RI, Bowman H, Zwolinski A, Swain P. Randomized testing optimizing parameters for flexible endoscopic suturing in the stomach using T-tag suture fasteners. Gastrointest Endosc. 2008;67:AB120.

9. Sclabas GM, Swain P, Swanstrom LL. Endoluminal methods for gastrotomy closure in natural orifice transenteric surgery (NOTES). Surg Innov. 2006;13:23-30.

10. Shaik SN, Fernandez-Esparrach G, Thompson CC. Use of a nitinol crown prototype for gastrostomy closure: evaluation in an ex vivo porcine model [abstract]. Gastroenterology 2008;134:A105-A106.

11. Sumiyama K, Gostout CJ, Rajan E, Bakken TA, Deters JL, Knipschield MA. Endoscopic full-thickness closure of large gastric perforations by use of tissue anchors. Gastroiontest Endosc. 2007;65:134-9.

12. Sumiyama K, Gostout CJ, Rajan E, Bakken TA, Knipschield MA, Chung S, Cotton PB, Hawes RH, Kalloo NA, Kantsevoy SV, Pasricha PJ. Transgastric cholecystectomy: transgastric accessibility to the gallblader improved with SEMF method and a novel multibending therapeutic endoscope. Gastrointest Endosc. 2007;65:1028-34.

13. Swain P. Park P, Mills T. Bard EndoCinch: the device, the technique and preclinical studies. Gastrointest Endosc Clin N Am. 2003;13:75-88.

14. Wu TK, Pietrocola D, Welch HF. New method of percutaneous gastrostomy using anchoring devices. Am J Surg. 1987;153:230-2. 